\title{
Kinetic Study of the Anaerobic Digestion of Swine Manure at Mesophilic Temperature: A Lab Scale Batch Operation
}

\author{
Gopi Krishna Kafle, Sang Hun Kim* \\ Department of Biosystems Engineering, Kangwon National University, Hyoja 2 Dong, Chuncheon, Korea
}

Received: July $12^{\text {th }}, 2012$; Revised: August $14^{\text {th }}, 2012$; Accepted: August $26^{\text {th }}, 2012$

\section{Abstract}

Purpose: The kinetic evaluation was performed for swine manure (SM) degradation and biogas generation. Methods: The SM was anaerobically digested using batch digesters at feed to inoculum ratio (F/I) of 1.0 under mesophilic conditions $\left(36.5^{\circ} \mathrm{C}\right)$. The specific gas yield was expressed in terms of gram total chemical oxygen demand (mL/g TCOD added) and gram volatile solids added (mL/g VS added) and their effectiveness was discussed. The biogas and methane production were predicted using first order kinetic model and the modified Gompertz model. The critical hydraulic retention time for biomass washout was determined using Chen and Hashimoto model. Results: The biogas and methane yield from SM was 346 and $274 \mathrm{~mL} / \mathrm{TCOD}$ added, respectively after 100 days of digestion. The average methane content in the biogas produced from SM was $79 \%$ and $\mathrm{H}_{2} \mathrm{~S}$ concentration was in the range of 3000-4108 ppm. It took around 32-47 days for $80-90 \%$ of biogas recovery and the TCOD removal from SM was calculated to be $85 \%$. When the specific biogas and methane yield from SM (with very high TVFA concentration) was expressed in terms of oven dried volatile solids (VS) basis, the gas yield was found to be over estimated. The difference in the measured and predicted gas yield was in the range of $1.2-1.5 \%$ when using first order kinetic model and $0.1 \%$ when using modified Gompertz model. The effective time for biogas production ( $\mathrm{T}_{\mathrm{Ef}}$ ) from SM was calculated to be in the range of 30-45 days and the critical hydraulic retention time (HRT ${ }_{\text {Critical }}$ for biomass wash out was found to be 9.5 days. Conclusions: The modified Gompertz model could be better in predicting biogas and methane production from SM. The HRT greater than 10 days is recommended for continuous digesters using SM as feedstock.

Keywords: Anaerobic digestion, Batch test, kinetic study, Mesophilic temperature, Swine manure

\section{Introduction}

Anaerobic biodegradation is a process in which complex compounds are degraded into methane, carbon dioxide and other gases by a bacteria consortium. Anaerobic process is an attractive alternative to aerobic treatment for the treatment of low to high strength wastewater, as well as for the production of biogas as an energy source. The anaerobic process has advantages over aerobic

\footnotetext{
*Comesponding author: Sang Hun Kim

Tel: +82-33-250-6492; Fax: +82-33-255-6406

E-mail: shkim@kangwon.ac.kr
}

treatment systems such as less sludge production, biogas generation, overall pathogen removal, lower energy consumption and lower space requirements (Kim and Hyun, 2004).

Anaerobic digestion of biodegradable waste will provide a solution for reducing both environmental problem and the consumption of fossil fuels. An additional advantage of anaerobic digestion is that, in addition to the produced biogas, a mineralized effluent that can be utilized as a bio-fertilizer with high nitrogen-phosphoruspotash (NPK) concentrations is obtained (Díaz et al., 2011). The quantity of waste produced from swine farms is about 
150000 tons/day in Korea and approximately $5.7 \%$ of the produced swine waste is disposed of by ocean dumping (KME, 2005; Shin et al., 2008). Swine manure treatment by anaerobic process could be most effective way of animal waste management (Zhang et al., 1997).

Anaerobic digestion treatment has been practiced in both batch and continuous digesters. Batch digesters are simpler in both construction and operation than continuous digesters. In the batch test, the selected substrate is incubated in closed vials or flasks at a specific temperature with a certain amount of methanogenic inoculum. After incubation, the degree of degradation of the substrate is evaluated at pre-set time intervals to determine the rate and ultimate extent of biodegradation (Raposo et al., 2009). These batch digesters are applied in large-scale installations and in laboratories when assessing the biochemical methane potential (BMP). To determine the suitability of a specific organic substrate for anaerobic digestion, the biochemical methane potential Remove (BMP) test has been proven to be a relatively simple and reliable method for the comparison of the extent and rates of waste conversion to methane (Hansen et al., 2004; Owen et al., 1979).

Kinetic modeling is an accepted approach to describe the specific parameters of the system performance. The results of kinetic studies obtained from experimental studies can be used for estimating treatment efficiencies of full-scale reactors with the same operational conditions. Different type's kinetic models have been applied successfully to anaerobic treatment using different types of reactors. Due to the microbial role in the anaerobic process, kinetic models particularly the first order kinetics were commonly applied to simulate the anaerobic biodegradation. Like the phase of bacterial growth, biogas production rate showed a rising limb and a decreasing limb which was indicated by exponential and linear equation (De Gioannis et al., 2009; Kumar et al., 2004). In addition, biogas accumulation could be simulated by exponential rise to maximum as well as modified Gompertz equations which were commonly used in the simulation of methane production (Lo et al., 2010; Li et al., 2011). The characteristics of swine manure (SM) varies from place to place based on types of feed used, amount of water used for flushing, and conditions under which SM is stored before treated in anaerobic digesters. Thus, before designing large scale batch or continuous anaerobic digesters for the treatment of particular SM or any substrates, it could be beneficial to evaluate the kinetic properties of the substrates under similar conditions in which continuous or batch reactors supposed to be operated. The determination of biogas and methane potential, biogas productions rate, degradation rate constant $(K)$, duration of lag phase $(\lambda)$, and critical hydraulic retention time ( $\mathrm{HRT}_{\text {Critical }}$ ) for biomass washout can be useful in model development and simulation of anaerobic digestion process for particular substrates used.

In this study, SM with very high volatile fatty acid concentrations (22030 mg/L) was anaerobically digested in batch digesters under mesophilic conditions. The main objective of the present study was to perform the kinetic evaluation for SM degradation and biogas generation using different kinetic models. The specific objectives are as follows: (1) to determine the biogas and methane potential, and biogas production rate of SM; (2) to determine the best fitted model for SM anaerobic digestion process and predict the biogas and methane production; (3) to determine the minimum HRT for biomass washout and effective biogas production period for SM under mesophilic conditions.

\section{Materials and Methods}

\section{Feed stock and inoculums}

Swine manure was obtained from a swine farm located in Gimje, Jeon-Buk Province, South Korea and stored at $4^{\circ} \mathrm{C}$. The mesophilic anaerobic digested sludge (inoculum) was obtained from a laboratory-scale fully stirred tank reactor (FSTR) installed at the Department of Biosystems Engineering, Kangwon National University, Korea. Swine manure was used as the substrate from which the inoculum was obtained. The characteristics of SM and the inoculum used for the tests are shown in Table 1.

\section{Batch digester startup and experimental design}

The batch anaerobic digestion test was carried out in $2.3 \mathrm{~L}$ glass bottles (liquid volume $2.0 \mathrm{~L}$ ) as shown in Figure 1. The experimental design for batch test is shown in Table 2. The feed to inoculum (F/I) ratio was maintained 1.0. The F/I ratio was calculated based on the initial VS of the substrate and inoculum. After adding the required amounts of inoculum and substrate, each 
digester was filled with tap water to maintain the designated volume. The batch digesters were checked for any leakage and flushed with $100 \%$ pure nitrogen for approximately 3 minutes to ensure anaerobic conditions. The anaerobic digesters were maintained at $36.5^{\circ} \mathrm{C}$ in a

Table 1. Characteristics of materials used

\begin{tabular}{lccc} 
Parameters & units & SM & Inoculum \\
\hline TS & $\%$ & 7.5 & 2.7 \\
VS & $\%$ & 5.6 & 1.4 \\
VS/TS & & 0.75 & 0.52 \\
$\mathrm{pH}$ & & 7.3 & 8.1 \\
\hline TVFA & $\mathrm{mg} / \mathrm{L}$ & 22030 & 3863 \\
\hline TA & $\mathrm{mg} / \mathrm{L}$ & 10530 & 14605 \\
\hline TVFA/TA ratio & & 2.100 & 0.264 \\
\hline TCOD & $\mathrm{mg} / \mathrm{L}$ & 121054 & 23050 \\
\hline $\mathrm{NH}{ }_{3}-\mathrm{N}$ & $\mathrm{mg} / \mathrm{L}$ & 6250 & - \\
\hline TKN & $\mathrm{mg} / \mathrm{L}$ & 7430 & - \\
$\mathrm{C} / \mathrm{N}$ & & 4.2 & - \\
\hline
\end{tabular}

$-:$ Not determined

$\mathrm{SM}$ : Swine manure

$\mathrm{C} / \mathrm{N}=\mathrm{TOC} / \mathrm{TKN}$

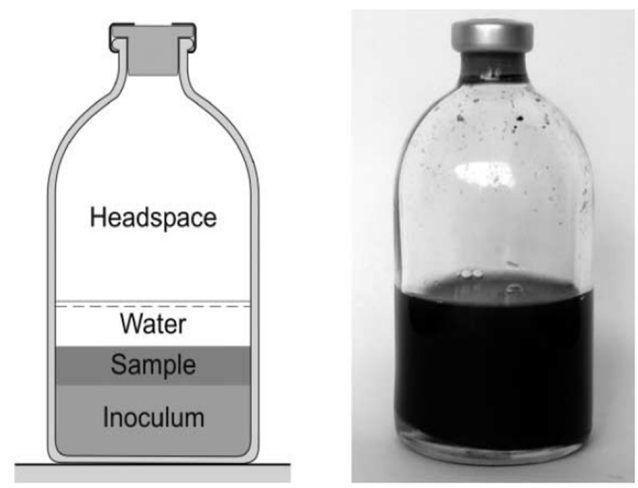

Figure 1. Batch test setup. temperature-controlled incubator. Each digester was mixed manually for one minute once a day just before the gas volume measurement. Assays with inoculums alone were also used as controls. Biogas and methane produced from inoculums were subtracted from the sample assays.

\section{Biogas volume/mass measurement and composition analysis}

The daily biogas production of each digester was determined by the volume of biogas produced, which was calculated from the volume and pressure in the headspace of the digester (EI-Mashad and Zhang, 2010). The pressure was measured using a WAL-BMP-Test system pressure gauge (type 3150, Wal, Germany). Daily pressure differences were converted into biogas volume using the following equation:

$$
\mathrm{V}_{\mathrm{B}}=\frac{\left(\mathrm{P}_{\mathrm{f}}-\mathrm{P}_{\mathrm{i}}\right) \cdot \mathrm{V}_{\mathrm{H}} \cdot \mathrm{C}}{\mathrm{R} \cdot \mathrm{T}}
$$

where

$\mathrm{V}_{\mathrm{B}}$ = Biogas volume (L)

$P_{i}=$ Initial pressure in the reactor head space (mbar)

$P_{f}=$ Final pressure in the reactor headspace after 24 hrs. (mbar)

$\mathrm{V}_{\mathrm{H}}=$ Volume of the headspace (L)

$\mathrm{C}=$ Molar volume $(22.41 \mathrm{~L} / \mathrm{mol})$

$\mathrm{R}$ = Universal gas constant (83.14 L mbar $/ \mathrm{K} / \mathrm{mol}$ )

$\mathrm{T}=$ Temperature $(\mathrm{K})$

Methane concentration $\left(\mathrm{CH}_{4}, \%\right)$, carbon dioxide concentration $\left(\mathrm{CO}_{2}, \%\right)$ and hydrogen sulfide concentration $\left(\mathrm{H}_{2} \mathrm{~S}, \mathrm{ppm}\right)$ in the biogas were analysed by using a gas analyser (BioGas Check - Geotechnical Instruments (UK),

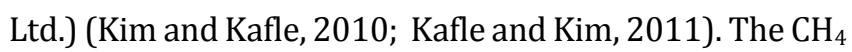

Table 2. Experimental design for test

\begin{tabular}{|c|c|c|c|c|c|c|c|c|c|c|}
\hline & \multirow[t]{3}{*}{$\mathrm{F} / \mathrm{M}$} & \multicolumn{4}{|c|}{ Organic loading rate (OLR) } & \multicolumn{3}{|c|}{ Volume added $(\mathrm{mL})$} & \multirow{3}{*}{$\begin{array}{c}\text { Total digester } \\
\text { contents } \\
\mathrm{mL}\end{array}$} & \multirow{3}{*}{$\begin{array}{c}\text { Head } \\
\text { space } \\
m L\end{array}$} \\
\hline & & \multicolumn{3}{|c|}{ SM } & Inoculum & SM & Inoculum & $\mathrm{H}_{2} \mathrm{O}$ & & \\
\hline & & $g V S / L^{a}$ & $g(V S+T V F A) / L^{b}$ & g TCOD/L & g VS/L & & & & & \\
\hline SM digester & 1.0 & 9 & 12.5 & 19.4 & 9 & 321 & 1290 & 389 & 2000 & 316 \\
\hline Blank digester & - & 0 & 0 & 0 & 9 & 0 & 1290 & 710 & 2000 & 316 \\
\hline
\end{tabular}

F/M: Feed to microbe ratio ( $\mathrm{g}$ VS substrate added/g VS inoculums added)

$\mathrm{g} \mathrm{VS/L^{a }}$ : Based on oven dried VS

$\mathrm{g}$ (VS+TVFA)/ $\mathrm{L}^{\mathrm{b}}$ : Measured based on oven dried VS plus VS added from TVFA concentration of SM (TVFA = $10000 \mathrm{mg} / \mathrm{L}$ equivalent to $1 \%$ VS (VDI 4360, 2006). 
and $\mathrm{CO}_{2}$ were measured by dual wavelength infrared cell with a reference channel, and $\mathrm{H}_{2} \mathrm{~S}$ was measured using an external gas pod connected to the gas analyser. The gas analyser was calibrated using certified gases $\mathrm{CH}_{4}(60$, $15.01, \%)$ and $\mathrm{CO} 2(40,15.01, \%)$. The gas composition $\left(\mathrm{CH}_{4}\right.$ and $\left.\mathrm{CO}_{2}, \%\right)$ was also cross-checked from time to time using a GC-2014 gas chromatograph (Shimadzu, Kyoto, Japan) equipped with a thermal conductivity detector. Helium was used as the carrier gas in the GC. The GC was calibrated using standard gases consisting of $\mathrm{CH}_{4}(60 \%)$ and $\mathrm{CO}_{2}(40 \%)$ on a volume basis (v/v). The data obtained from two gas-measuring instruments differed by only $1 \%-1.8 \%$ in gas composition $\left(\mathrm{CH}_{4}\right.$ and $\mathrm{CO}_{2}, \%$ ) when compared with the biogas. The measured wet biogas and methane volumes were adjusted to the volumes at standard temperature $\left(0^{\circ} \mathrm{C}\right)$ and pressure $(1$ atm) as follows:

$$
\mathrm{V}_{\mathrm{STP}}=\frac{\mathrm{V}_{\mathrm{T}} \times 273 \times\left(760-\mathrm{p}_{\mathrm{w}}\right)}{(273+\mathrm{T}) \times 760}
$$

where

$\mathrm{V}_{\mathrm{STP}}=$ Volume of gas measured at standard temperature and pressure (L)

$\mathrm{V}_{\mathrm{T}}=$ Volume of gas measured at temperature $\mathrm{T}(\mathrm{L})$

$\mathrm{T}=$ Temperature of the fermentation gas or of the ambient space $\left({ }^{\circ} \mathrm{C}\right)$

$\mathrm{p}_{\mathrm{w}}=$ Vapor pressure of the water as a function of temperature $(\mathrm{mm} \mathrm{Hg})$

The corrected methane content $\left(\mathrm{CH}_{4}\right.$ Corr $)$ in the biogas was calculated using equation (3) as proposed in German standard procedure (VDI 4630, 2006).

$$
\mathrm{CH}_{4 \text { Corr }}=\frac{\mathrm{C}_{\mathrm{CH}_{4}} \times 100}{\mathrm{C}_{\mathrm{CH}_{4}}+\mathrm{C}_{\mathrm{CO}_{2}}}
$$

where

$$
\begin{aligned}
\mathrm{CH}_{4} \text { Corr }= & \text { Corrected methane content in the dry gas ( } \% \\
& \text { by volume) } \\
\mathrm{C}_{\mathrm{CH} 4}= & \text { Measured methane content in the gas (\% by } \\
& \text { volume) } \\
\mathrm{C}_{\mathrm{CO} 2}= & \text { Measured carbon dioxide content in the gas } \\
& (\% \text { by volume). }
\end{aligned}
$$

During batch digestion, the biogas production rates and methane content change considerably over the digestion time. The methane content on intermediate days was calculated using linear interpolation by the INTERP1 function in Matlab software R2011b (7.13.0.564). The weighted average methane content over the digestion period was calculated as follows.

$$
\mathrm{CH}_{4 \text { Corr, } \mathrm{WA}}(\%)=\frac{\sum_{\mathrm{i}=1}^{\mathrm{n}} \mathrm{BP}_{\mathrm{i}} \times \mathrm{CH}_{4} \text { Corr, } \mathrm{i}}{\sum_{\mathrm{i}=1}^{\mathrm{n}} \mathrm{BP}_{\mathrm{i}}}
$$

Based on the weighted average corrected methane content and the interpolated data, the standard deviation $(\sigma)$ was calculated in Excel software 2007 as follows:

$$
\sigma=\sqrt{\frac{\sum\left(\mathrm{CH}_{4 \mathrm{Cor}, \mathrm{i}}-\mathrm{CH}_{4 \mathrm{Cor}, \mathrm{WA}}\right)^{2}}{\mathrm{n}-1}}
$$

where

$\mathrm{BP}_{\mathrm{i}}=$ Biogas production on day $\mathrm{i}$

$\mathrm{CH}_{4}$ Corr, $\mathrm{i}=$ Corrected methane content on day $\mathrm{i}$

$\mathrm{n} \quad=$ Number of observations

\section{Analytical methods and organic matter removal}

Total solids (TS) and volatile solids (VS) were determined in the well-mixed samples in triplicate according to standard methods (APHA, 1998). The closed reflux titration method was used for TCOD analysis. $\mathrm{pH}$ value was determined using a pH meter (YK-2001 PH, Taiwan) at digester temperature $\left(36-38^{\circ} \mathrm{C}\right)$. Total Kjeldahl nitrogen (TKN) was analyzed using a Kjeldahl apparatus (Kjeltec 2100 , Foss, Sweden). The ammonia nitrogen $\left(\mathrm{NH}_{3}-\mathrm{N}\right)$ was measured using the Nessler method and was determined using a spectrophotometer (DR 2500, Hach, USA). TVFA, TA (total alkalinity) and TVFA/TA ratio were determined using the Nordmann-titration method (Kafle and Kim, 2011; Kafle et al., 2012a).The TOC (total organic carbon) was calculated using relation, TOC=VS/1.8 (Haug, 1993).

The mass removal in the form of biogas at the end of the experiment was calculated using a formula shown in equation (6) (Kafle et al., 2012b). The density of $\mathrm{CH}_{4}$ was taken as $0.000668 \mathrm{~g} / \mathrm{mL}$, and the density of $\mathrm{CO}_{2}$ was taken as $0.00184 \mathrm{~g} / \mathrm{mL}$. The TCOD removal of the feed during batch test was calculated using equation (7).

$$
\mathrm{BR}=\frac{\mathrm{V}_{0} \times \rho_{\text {mix }}}{\mathrm{m}}
$$


TCOD removal $(\%)=\frac{\mathrm{V}_{0} \times \mathrm{CH}_{4 \text { Corr }}}{320 \times \mathrm{m}}$

where

BR = Mass of biogas removed per gram VS or TCOD added (g/g VS added or g/g TCOD added)

$\mathrm{V}_{0}=$ Volume of biogas produced $(\mathrm{ml}$, at STP)

$\rho_{\text {mix }}=$ Mass concentration of $\mathrm{CH}_{4}+\mathrm{CO}_{2}$ in the biogas (g/mL)

$\mathrm{m}=$ VS or TCOD added (g)

\section{Kinetic model and statistical indicators}

Assuming first-order kinetics for the hydrolysis of particulate organic matter, the cumulative methane production can be described by means of equation (8).

$$
\mathrm{G}(\mathrm{t})=\mathrm{G}_{\mathrm{o}} \times\left(1-\mathrm{e}^{(-\mathrm{Kt})}\right)
$$

where

$\mathrm{G}(\mathrm{t})=$ The cumulative methane yield at digestion time $\mathrm{t}$ days (mL/g TCOD added)

$\mathrm{G}_{\mathrm{o}}=$ Methane potential of the substrate $(\mathrm{mL} / \mathrm{g}$ TCOD added)

$\mathrm{K}=$ Biogas or methane production rate constant (first order disintegration rate constant) (1/day)

$\mathrm{t} \quad=$ Time (days) .

Apart from specific methane yield and the cumulative methane yield, the duration of the lag phase is also an important factor in determining the efficiency of anaerobic digestion. The lag phase $(\lambda)$ can be calculated with the modified Gompertz model as follows:

$$
M=P \cdot \exp \left\{-\exp \left[\frac{\mathrm{R}_{\max } \cdot \mathrm{e}}{\mathrm{P}}(\lambda-\mathrm{t})+1\right]\right\}
$$

where

$\mathrm{M}$ = Cumulative methane production (mL/g TCOD)

$\mathrm{P} \quad=$ Methane production potential (mL/g TCOD)

$\mathrm{R}_{\max }=$ Maximum methane production rate (mL/g TCOD-d)

$\lambda=$ Lag phase (day)

$\mathrm{t} \quad=$ Time (day)

$\mathrm{e} \quad=\exp (1)=2.7183$

A nonlinear least-square regression analysis was performed using SPSS program (IBM SPSS statistics 19 (2010)) to determine $K, R_{\max }, \lambda$, and the predicted biogas and methane yield. At the same time, the standard error and coefficient of determination or correlation coefficient $\left(R^{2}\right)$ were also obtained. The predicted methane yield obtained from the SPSS program was plotted with the measured methane yield using Matlab software R2011b (7.13.0.564). The statistical indicators $\mathrm{R}^{2}$ and root mean square error (RMSE) were calculated (Bhattarai, et al., 2012a; Bhattarai, et al., 2012b):

$$
R M S E=\left(\frac{1}{m} \sum_{j=1}^{m}\left(\frac{d_{j}}{Y_{j}}\right)^{2}\right)^{\frac{1}{2}}
$$

where

$\mathrm{m}=$ Number of data pairs

$\mathrm{j}=\mathrm{j}^{\text {th }}$ values

$\mathrm{Y}=$ Measured methane yield $(\mathrm{mL} / \mathrm{g} \mathrm{VS})$

$\mathrm{d}=$ Deviations between experimental and predicted methane yield

\section{Critical retention time}

Chen and Hashimoto's model (equation (11)) was used to determine the critical retention time for SM.

$$
\mathrm{G}(\mathrm{t})=\mathrm{G}_{0}\left(1-\frac{\mathrm{K}_{\mathrm{CH}}}{\mathrm{HRT} \times \mu_{\mathrm{m}}+\mathrm{K}_{\mathrm{CH}}-1}\right)
$$

The equation (11) can be converted to equation (12).

$$
\frac{\mathrm{G}_{0}}{\mathrm{G}_{0}-\mathrm{G}(\mathrm{t})}=\frac{\mathrm{HRT} \mu_{\mathrm{m}}}{\mathrm{K}_{\mathrm{CH}}}+1-\frac{1}{\mathrm{~K}_{\mathrm{CH}}}
$$

where

$\mathrm{G}(\mathrm{t})=$ The cumulative methane yield at digestion time $\mathrm{t}$ days (mL/g TCOD added)

$\mathrm{G}_{0}=$ Methane potential of the substrate $(\mathrm{mL} / \mathrm{g}$ TCOD added)

$\mathrm{K}_{\mathrm{CH}}=$ Chen and Hashimoto kinetic constant (dimension less)

$\mu_{\mathrm{m}} \quad=$ Maximum specific growth rate of microorganisms (1/day)

When $\mathrm{G}_{0} /\left(\mathrm{G}_{0}-\mathrm{G}(\mathrm{t})\right)$ was plotted against hydraulic retention time (HRT), a straight line with the slope $\mu_{\mathrm{m}} / \mathrm{K}_{\mathrm{CH}}$ and the intercept $1-1 / \mathrm{K}_{\mathrm{CH}}$ was obtained. The critical retention time (HRT critical) when biomass washout takes place was determined using equation (13). The shorter the HRT critical is, the better reactor will operate. 


$$
\operatorname{HRT}_{\text {Critical }}=\frac{1}{\mu_{\mathrm{m}}}
$$

\section{Results and Discussion}

\section{Biogas yield and production rate}

The cumulative biogas yield (mL/g TCOD) and biogas production rate (mL/g TCOD-d) from SM and inoculum are shown in Figure 2(a) and Figure 2(b), respectively. The biogas production from SM shown in Figure 2 was plotted after subtracting the biogas production from blank digesters with SM digesters. The batch test lasted for 100 days. Biogas production started immediately on the first day of digestion in all the digesters. On the first
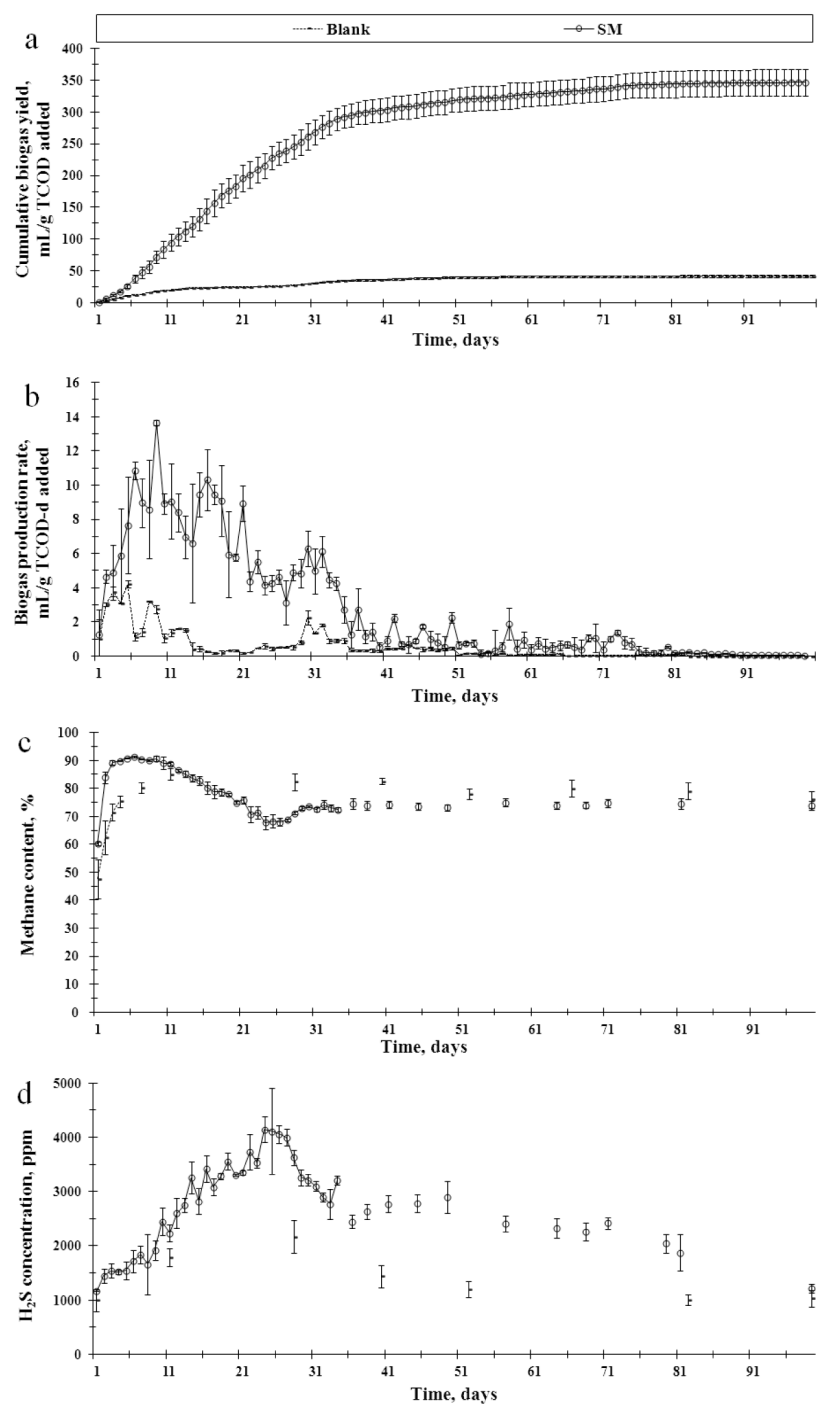

Figure 2. (a) Cumulative biogas yield; (b) biogas production rate; (c) methane content; (d) $\mathrm{H}_{2} \mathrm{~S}$ concentration in the biogas produced from SM and blank (inoculum) under mesophilic conditions. day of digestion (day 1), the biogas production from SM digesters (1.3 mL/g TCOD) was only slightly higher than from blank digesters (1.0 mL/ g TCOD). However, from day 2, the biogas production rate from SM digester's increased greatly compared to blank digesters. This may indicate fast acclimation of the microorganisms to the feedstock. The biogas production rate in SM digesters increased continuously up to day 6 and then maintained biogas production rate in the range of $9.0-13.6 \mathrm{~mL} / \mathrm{g}$ TCOD with some fluctuations during days 6-21. On day 22 biogas production rate decreased from $9.0 \mathrm{~mL} / \mathrm{g}$ TCOD to $4.4 \mathrm{~mL} / \mathrm{g}$ TCOD and then maintained almost constant value (4.3-6.2 mL/g TCOD) with some fluctuations until day 34 . From day 35 the biogas production continuously dropped until day 40 and thereafter maintained very low level (0.3-2.2 mL/g TCOD) of biogas production rate till day 76. The biogas production from SM digesters almost ceased from day 77 . The peak values of daily biogas production rate for SM was calculated to be $13.6 \mathrm{~mL} / \mathrm{g}$ TCOD on day 9. The specific biogas yield (mL/g TCOD) increased until about day 35 and gradually leveled off thereafter (Fig, 1(a)). The average biogas yield for SM was $346 \mathrm{~mL} / \mathrm{g}$ TCOD after 100 days of digestion (Table 3).

\section{Biogas composition and organic matter removal}

Figure 2(c) shows the average value of methane concentration in the biogas produced from SM digesters and inoculums digesters. The methane concentration in the biogas produced from blank digester was around $48 \%$ on the day 1 and it continuously increased until day 11 (reached up to $85 \%$ ), and it remained almost constant thereafter. The high value of methane concentration in biogas produced from blank digesters starting from first day of digestion indicated that the used inoculum was active enough to use for the test. The methane concentration in the biogas produced from SM digester was around $63 \%$ on day 1 and it rapidly increased on second and third day and reached peak value of $90 \%$. The methane content remained almost constant during days 4-10. From day 11 the methane content in SM digester decreased continuously and reached a value of around $68 \%$ on day 24 . During days $25-32$, the methane content slightly increased and maintained around $74 \%$ on day 32 and thereafter it remained almost constant (73\%-75\%) with some fluctuations until end of the test. The weighted average methane content for SM was $79 \%$. Thus average 
Kafle and Kim. Kinetic Study of the Anaerobic Digestion of Swine Manure at Mesophilic Temperature: A Lab Scale Batch Operation

Journal of Biosystems Engineering • Vol. 37, No. 4, 2012 • www.jbeng.org

Table 3. Gas potential, BR and TCOD removal

\begin{tabular}{|c|c|c|c|}
\hline Feed composition (VS basis) & Units & Mean value & $\operatorname{SD}(n=3)$ \\
\hline \multicolumn{4}{|l|}{ Based on TCOD input } \\
\hline Biogas yield & $\mathrm{mL} / \mathrm{g}$ TCOD added & 346 & 21 \\
\hline Methane yield & $\mathrm{mL} / \mathrm{g}$ TCOD added & 274 & 15 \\
\hline Methane contenta & $\%$ & 79.0 & 8 \\
\hline TCOD removal & $\%$ & 85 & 5 \\
\hline BR & g/ g TCOD added & 0.317 & 0.020 \\
\hline \multicolumn{4}{|l|}{ Based on measured VS input ${ }^{b}$} \\
\hline Biogas yield & $\mathrm{mL} / \mathrm{g}$ VS added & 747 & 44 \\
\hline Methane yield & $\mathrm{mL} / \mathrm{g}$ VS added & 590 & 33 \\
\hline VS removal & $\%$ & 73 & 5 \\
\hline BR & g/ g VS added & 0.682 & 0.043 \\
\hline \multicolumn{4}{|c|}{ Based on both measured VS and TVFA input ${ }^{\mathrm{C}}$} \\
\hline Biogas yield & $\mathrm{mL} / \mathrm{g}(\mathrm{VS}+\mathrm{TVFA})$ added & 536 & 31 \\
\hline Methane yield & $\mathrm{mL} / \mathrm{g}(\mathrm{VS}+\mathrm{TVFA})$ added & 427 & 26 \\
\hline VS removal & $\%$ & 53 & 3 \\
\hline BR & $\mathrm{g} / \mathrm{g}(\mathrm{VS}+\mathrm{TVFA})$ added & 0.491 & 0.031 \\
\hline
\end{tabular}

${ }^{\mathrm{a}} \mathrm{SD}$ calculated using equation (5)

${ }^{\mathrm{b}}$ Mass of VS input = VS measured from drying oven

${ }^{c}$ Mass of VS input $=$ VS measured from drying oven plus equivalent VS added from TVFA

concentration of the substrate $(10000 \mathrm{mg} / \mathrm{L}$ TVFA $=1 \%$ VS $($ VDI 4360,2006$)$

methane yield from SM was calculated to be $275 \mathrm{~mL} / \mathrm{g}$ TCOD added (Table 3). Gonzảlez-Fernảndez et al. (2011) reported methane yield of $246 \mathrm{~mL} / \mathrm{g}$ COD added from SM which is similar to our study.

Figure 2(d) shows the average value of hydrogen sulfide $\left(\mathrm{H}_{2} \mathrm{~S}\right)$ concentration in the biogas produced from both SM and blank digesters. The inoculums used for the test produced biogas with high $\mathrm{H}_{2} \mathrm{~S}$ concentration (1000$2166 \mathrm{ppm}$ ). The SM digesters produced biogas with higher concentration of $\mathrm{H}_{2} \mathrm{~S}$ compared to blank digesters. The $\mathrm{H}_{2} \mathrm{~S}$ concentration in SM was 1160 ppm on first day and it continuously increased and reached peak value of $4108 \mathrm{ppm}$ on day 24 . From day 25 the $\mathrm{H}_{2} \mathrm{~S}$ concentration decreased continuously till day $33\left(\mathrm{H}_{2} \mathrm{~S}=2800 \mathrm{ppm}\right)$ and thereafter maintained almost constant value until the end of the test. When comparison is made between Figure 2(c) and Figure 2(d) then it can be seen that during days 1-9 when $\mathrm{H}_{2} \mathrm{~S}$ concentration was below 2000 ppm then there was not seen any effect on methane content but from day 10 when $\mathrm{H}_{2} \mathrm{~S}$ continuously increased and reached value greater than $3000 \mathrm{ppm}$ then rapid drop in methane content was seen. Also, when $\mathrm{H}_{2} \mathrm{~S}$ concentration decreased continuously during days 25-33, the methane contents increased. Later on when $\mathrm{H}_{2} \mathrm{~S}$ concentration was almost constant with value below $3000 \mathrm{ppm}$ during days 33-100, the methane content remained almost constant. Thus results showed that methanogens activity could be slightly negatively affected by $\mathrm{H}_{2} \mathrm{~S}$ concentration up to 2000-2500 ppm but it can cause serious inhibition to methanogens when the $\mathrm{H}_{2} \mathrm{~S}$ concentration increased beyond $3000 \mathrm{ppm}$.

The TCOD removal and BR for SM was calculated to be $85 \%$ and $0.317 \mathrm{~g} / \mathrm{g}$ TCOD added respectively (Table 3). The characteristics of final SM digesters contents are shown in Table 4. The final $\mathrm{pH}$ was 8.0 and TVFA/TA ratio was 0.07 , respectively. The final $\mathrm{pH}$ and TVFA/TA ratio showed that there was no accumulation of VFA and inhibition to methanogens. Islam et al. (2012) noticed TVFA/TA ratios as important criteria for judging stability in batch digesters during anaerobic co-digestion of food waste with SM. Similalry, Raposo et al. (2009) observed stable digestion operation for TVFA/TA ratio in the range of $0.30-0.40$ or less but at around TVFA/TA ratio of 0.70 destabilization of digester was observed.

\section{Specific gas yield and BR expressed in terms of TCOD and VS added}

The net volume occupied by gas varies with the type of 


\begin{tabular}{|c|c|c|c|}
\hline \multirow[t]{2}{*}{ Characteristics } & Units & Value & \\
\hline & & Average & SD \\
\hline TS & $\%$ & 2.31 & 0.02 \\
\hline VS & $\%$ & 1.13 & 0.02 \\
\hline VS/TS & & 0.49 & 0.01 \\
\hline $\mathrm{pH}$ & & 8.00 & 0.04 \\
\hline TVFA & $\mathrm{mg} / \mathrm{L}$ & 1335 & 126 \\
\hline TA & $\mathrm{mg} / \mathrm{L}$ & 18225 & 152 \\
\hline TVFA/TA ratio & & 0.07 & 0.01 \\
\hline $\mathrm{NH}_{3}-\mathrm{N}$ & $\mathrm{mg} / \mathrm{L}$ & 2960 & 87 \\
\hline
\end{tabular}

SD: Standard deviations $(n=3)$

substrate, the reactor solid content, the rate of gas production, and the degree of compaction. This variability makes volume a poor basis for calculations. A mass basis is more reliable for research, since the net reactor mass is not affected by transient volume variations (Richards et al., 1999). Richard et al. (1999) reported that the mass of biogas removed (BR) includes both converted substrate mass and biogas originated from water hydrolytically consumed. Thus, the calculated BR should be higher than the measured VS destructions.

The excessive loss of VFAs and other volatile compounds during the drying process of VS measurement can cause error in determining the actual biogas potential of the substrate (mL/g VS added) and the VS destruction (Hayward and Pavlicick, 1990). Similarly, Kreuger et al. (2011) demonstrated that the methane yields calculated based on uncorrected TS and VS are unreliable. According to the German standard procedure (VDI 4360, 2006), if the substrates (like silages) contain significant proportion of readily volatile organic acids, the organic dry matter input should be increased by the proportion of the steam-volatile organic acids. A concentration of 10000 $\mathrm{mg} / \mathrm{L}$ acetic acid equivalent means an increase of $1 \%$ absolute in the VS content with respect to the moist mass (VDI 4360, 2006). The SM used in this study contained very high concentration of TVFA $(22030 \mathrm{mg} / \mathrm{L})$ which can be the main reason for resulting in a higher value of biogas and methane yield (mL/g VS added) (Table 4) compared to values reported in different literatures (Hashimoto, 1983; Zhang et al., 2011; Asam et al., 2011). When the gas yield and BR were calculated by including both the VS added from the substrate (oven dried) and equivalent VS added from the TVFA concentration of the substrate, the values were significantly reduced (Table 3 ). Thus the results showed that for the substrates containing higher VFA concentrations, the error occurred in determining gas yield could be corrected by adding up the equivalent VS from the VFA concentration of the substrate used.

When the gas yield was calculated in terms of g TCOD added (Table 3), the values obtained for SM was similar as reported in the previous study (Gonzảlez-Fernảndez et al., 2011). The process of TCOD measurement can be more precise than the VS measurement process because during TCOD measurement there is no chance for loss of the VFAs and other volatile compounds as in the case of VS measurement process. Thus it showed that the calculation of biogas and methane potential in terms of VS added (measured in drying oven) can be over estimated. However, the TCOD measurement process is more tedious, expensive and not eco- friendly than the VS measurement process. Although the biogas and methane potential of feed have been expressed in terms of $\mathrm{g}$ VS added in many literatures (Hashimoto, 1983; Zhang et al., 2011; Asam et al., 2011), the results of our study (Table 3) showed that the gas potential expressed in terms of g TCOD added could be more precise than expressed in terms of $\mathrm{g}$ VS added for the substrates (like SM) with higher TVFA concentration.

\section{Results of kinetic study}

Table 5 summarizes the results of kinetic study using first order kinetic model and modified Gompertz model, respectively. The biogas production rate constant $\left(\mathrm{K}_{\mathrm{b}}\right)$ and methane production rate consta $\mathrm{nt}\left(\mathrm{K}_{\mathrm{m}}\right)$ for SM was calculated to be 0.042 and 0.045 , respectively using first order kinetic model. Similalry, lag phase of 2.0 and 1.1 days was calculated for biogas and methane production, respectively using modified Gompertz model. To evaluate the soundness of the model results, the predicted values of biogas and methane yield were plotted against the measured values as shown in Figure 3 and Figure 4. The RMSE value was in the range of 0.9293 to 0.9407 , and the $\mathrm{R}^{2}$ value was in the range of 0.9920 to 0.9939 when using first order kinetic model. Similarly, the RMSE value was in the range of 1.0891-1.3133, and the $R^{2}$ value was in the range of 0.9947 to 0.9962 when using modified Gompertz model. Both the models used were found to be better fitted to anaerobic digestion process of SM as the difference between measured and predicted gas yield is 
Kafle and Kim. Kinetic Study of the Anaerobic Digestion of Swine Manure at Mesophilic Temperature: A Lab Scale Batch Operation

Journal of Biosystems Engineering • Vol. 37, No. 4, 2012 • www.jbeng.org

Table 5. Parameters estimated from first order kinetic model and modified Gompertz model for anaerobic digestion of SM under mesophilic conditions

\begin{tabular}{|c|c|c|c|c|c|}
\hline & \multirow[t]{2}{*}{ Units } & \multicolumn{2}{|c|}{ SM } & \multicolumn{2}{|c|}{ Blank (Inoculum) } \\
\hline & & $\begin{array}{l}\text { Using } \\
\text { biogas yield } \\
\text { data }\end{array}$ & $\begin{array}{c}\text { Using } \\
\text { methane yield } \\
\text { data }\end{array}$ & $\begin{array}{l}\text { Using } \\
\text { biogas yield } \\
\text { data }\end{array}$ & $\begin{array}{c}\text { Using } \\
\text { methane yield } \\
\text { data }\end{array}$ \\
\hline \multicolumn{6}{|l|}{ First order kinetic model } \\
\hline $\mathrm{K}\left(\mathrm{K}_{\mathrm{b}}\right.$ or $\left.\mathrm{K}_{\mathrm{m}}\right)$ & 1/day & 0.042 & 0.045 & 0.052 & 0.050 \\
\hline Standard error & & 0.004 & 0.001 & 0.001 & 0.001 \\
\hline $\mathrm{R}^{2}$ & & 0.9720 & 0.979 & 0.973 & 0.977 \\
\hline Experimental biogas or methane yield & $\mathrm{mL} / \mathrm{g}$ TCOD added & 346.2 & 273.5 & 54.0 & 42.0 \\
\hline Predicted biogas or methane yield & $\mathrm{mL} / \mathrm{g}$ TCOD added & 341.1 & 270.3 & 53.7 & 41.7 \\
\hline $\begin{array}{l}\text { Difference between measured } \\
\text { and predicted gas yield }\end{array}$ & $\%$ & 1.5 & 1.2 & 0.6 & 0.7 \\
\hline \multicolumn{6}{|l|}{ Modified Gompertz model } \\
\hline $\mathrm{Rm}$ & $\mathrm{mL} / \mathrm{g}$ TCOD-d & 9.9 & 8.0 & 1.3 & 1.0 \\
\hline Standard error & & 0.1 & 0.1 & 0.0 & 0.030 \\
\hline Lag phase & days & 2.0 & 1.1 & -7.7 & -6.05 \\
\hline Standard error & & 0.3 & 0.3 & 0.8 & 0.8 \\
\hline $\mathrm{R}^{2}$ & & 0.9950 & 0.9940 & 0.974 & 0.974 \\
\hline Experimental biogas or methane yield & $\mathrm{mL} / \mathrm{g}$ TCOD added & 346.2 & 273.5 & 54.0 & 42 \\
\hline Predicted biogas or methane yield & $\mathrm{mL} / \mathrm{g}$ TCOD added & 345.8 & 273.2 & 53.8 & 41.9 \\
\hline $\begin{array}{l}\text { Difference between measured } \\
\text { and predicted gas yield }\end{array}$ & $\%$ & 0.1 & 0.1 & 0.4 & 0.2 \\
\hline
\end{tabular}

With $95 \%$ confidence interval

$\mathrm{K}_{\mathrm{b}}$ : Biogas production rate constant

$\mathrm{K}_{\mathrm{m}}$ : Methane production rate constant
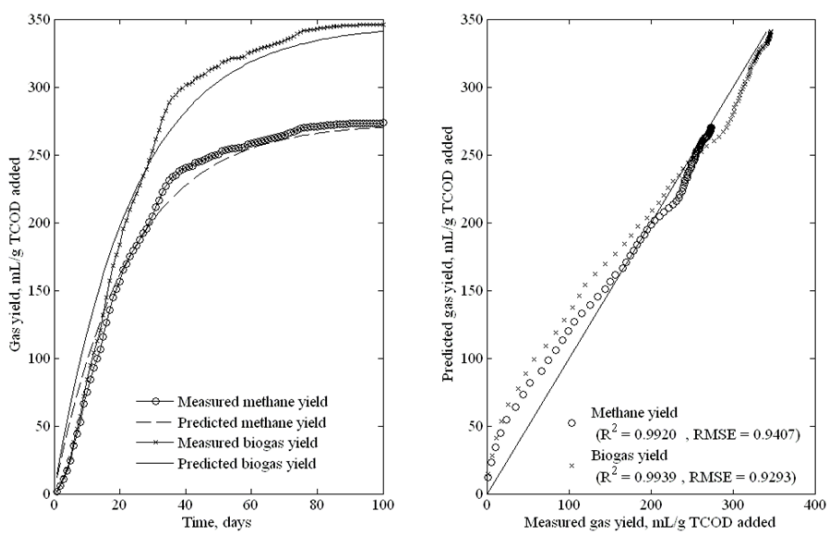

Figure 3. Plot of measured and predicted gas yield using first order kinetic model with statistical indicators.

less than $2 \%$ and $\mathrm{R}^{2}$ value is greater than 0.99 in both the cases. Raposo et al. (2009) reported an error of $10 \%$ or less in predicting methane production from sunflower oil cake when using a first-order kinetic model. The difference between measured and predicted gas yield was
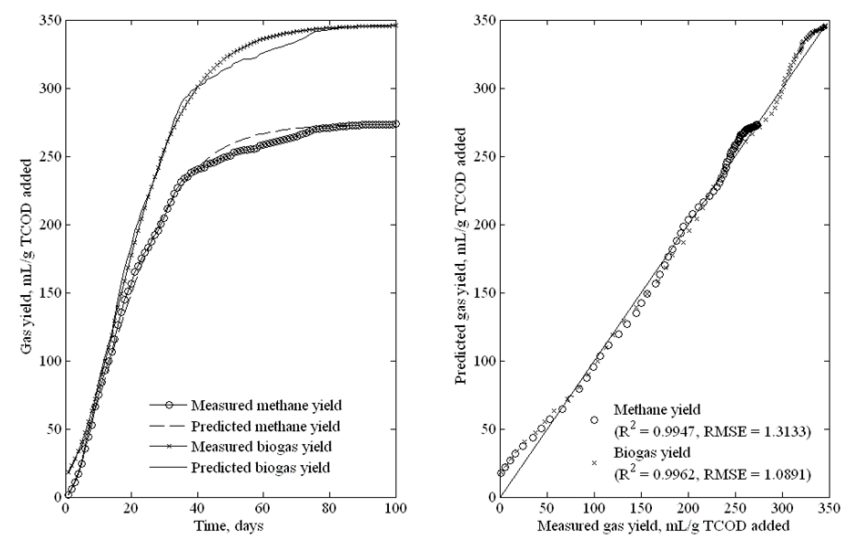

Figure 4. Plot of measured and predicted gas yield using modified Gompertz model with statistical indicators.

lower and $\mathrm{R}^{2}$ value was higher when using modified Gompertz model compared to first order kinetic model. Thus among two models used, modified Gompertz model was found to be better fitted to experimental results. 
Table 6. Effective biogas production period and critical retention time for anaerobic digestion of SM under mesophilic conditions

\begin{tabular}{lcc} 
Parameters & Unit & Values \\
\hline $\mathrm{K}_{\mathrm{CH}}$ & & 0.537 \\
$\mu_{\mathrm{m}}$ & 1/days & 0.105 \\
$\mathrm{HRT}$ Critical & days & 9.5 \\
$\mathrm{~T}_{50}$ & days & 19 \\
$\mathrm{~T}_{80}$ & days & 32 \\
$\mathrm{~T}_{90}$ & days & 47 \\
$\mathrm{~T}_{(80) \mathrm{Ef}}$ & days & 30 \\
\hline $\mathrm{T}_{(90) \mathrm{Ef}}$ & days & 45 \\
\hline
\end{tabular}

$\mathrm{K}_{\mathrm{CH}}=$ Chen and Hashimoto kinetic constant

$\mu_{m}=$ Maximum specific growth rate of microorganisms

$\mathrm{HRT}_{\text {Critical }}=$ Critical hydraulic retention time

$\mathrm{T}_{50}=$ Time period for $50 \%$ of total biogas production

$\mathrm{T}_{80}=$ Time period for $80 \%$ of total biogas production

$\mathrm{T}_{90}=$ Time period for $90 \%$ of total biogas production

$\mathrm{T}_{(80) \mathrm{Ef}}=$ Effective biogas production duration for $80 \%$ of biogas production $\left(T_{80}-\lambda\right)$

$\mathrm{T}_{(90) \mathrm{Ef}}=$ Effective biogas production duration for $90 \%$ of biogas production $\left(T_{90}-\lambda\right)$

\section{$\mathrm{T}_{\mathrm{Ef}}$ and $\mathrm{HRT}_{\text {Critical }}$ for SM under mesophilic conditions}

Table 6 shows the time period required for different $\%$ of biogas production, $\mathrm{T}_{\mathrm{Ef}}$, and kinetic parameters obtained for SM from Chen and Hashimoto model. The effective biogas production period ( $\mathrm{T}_{\mathrm{EF}}$ ) was calculated by subtracting the lag time $(\lambda)$ from the time period taken for $80 \%$ of total biogas production $\left(\mathrm{T}_{80}\right)$ or from the time period taken for $90 \%$ of total biogas production ( $\left.\mathrm{T}_{90}\right)$ (Table 6 ). The $\mathrm{T}_{(80) \text { Ef }}$ and $\mathrm{T}_{(90) \text { ef }}$ was found to be 30 and 45 days, respectively. Thus for anaerobic digestion of SM under mesophilic conditions, the HRT in the range of 30-45 days is recommended. Similarly, HRT Critical $_{\text {for SM was found to }}$ be 9.5 days. Thus, while running continuous digesters using SM with high TVFA concentrations, its HRT should be greater than 9.5 days to prevent the biomass washout under mesophilic conditions.

\section{Conclusions}

In this study, SM was anaerobically digested in batch digesters under mesophilic conditions. The used SM was found to be potential substrate for anaerobic digestion with biogas and methane potential of 346 and $274 \mathrm{~mL} /$ TCOD added, respectively. For the SM with higher TVFA concentration, the gas yield is recommended to be expressed in terms of TCOD added compared to VS added. The results showed that both first order kinetic model and modified Gompertz model can be suitable for expressing the microbial kinetics of anaerobic decomposition of SM. The modified Gompertz model better fitted the experimental results than first order kinetic model. For operating the field scale SM anaerobic digesters with continuous feeding, the HRT of 30-45 days is recommended to maximize the biogas recovery from the system. Similarly, the minimum HRT of 10 days is recommend to prevent the washout of the biomass.

\section{Conflict of Interest}

No potential conflict of interest relevant to this article was reported.

\section{Acknowledgements}

This work was supported by a research grant from the Rural Development Administration (RDA), Republic of Korea.

\section{References}

APHA. 1998. Standard Methods for the Examination of Water and Wastewater, $20^{\text {th }}$ ed. American Public Health Assoc., Washington, DC.

Asam, Z. U. Z., T. G. Poulsen, A. S. Nizami, R. Rafique, G. Kiely and J. D. Murphy. 2011. How can we improve biomethane production per unit of feedstock in biogas plants? Applied Energy 88:2013-2018.

Bhattarai, S., D. H. Kim and J. H. Oh. 2012a. Simulation and model validation of pneumatic conveying drying for wood dust particles. Journal of Biosystems Engineering 37(2):82-89.

Bhattarai, S., J. H. Oh, S. H. Euh, G. K. Kafle and D. H. Kim. 2012b. Simulation and model validation of sheet and tube type photovoltaic thermal solar system and conventional solar collecting system in transient states. Solar Energy Materials and Solar Cells 103:184-193.

De Gioannis, G., A. Muntoni, G. Cappai and S. Milia. 2009. Landfill gas generation after mechanical biological treatment of municipal solid waste. Estimation of gas 
generation rate constants. Waste Management 29: 1026-1034.

Díaz, J. P., I. P. Reyes, M. Lundin and I. S. Horvảth. 2011. Co-digestion of different waste mixtures from agroindustrial activities: Kinetic evaluation and synergetic effects. Bioresource Technology 102:10834-10840.

EI-Mashad, H. M. and R. Zhang. 2010. Biogas production from co-digestion of dairy manure and food waste. Bioresource Technology 101:4021-4028.

Gonzảlez-Fernảndez, C., B. Molinuevo-Salces and M. C. García-Gonzảlez. 2011. Evaluation of anaerobic codigestion of microalgal biomass and swine manure via response surface methodology. Applied Energy 88: 3448-3453.

Hansen, T., J. Schmidt, I. Angelidaki, E. Marca, J. Jansen, H. Mosbæk and T. Christensen. 2004. Method of determination of methane potentials of solid organic waste. Waste Management 24:393-400.

Hashimoto, A. G. 1983. Thermophilic and mesophilic anaerobic fermentation of swine manure. Agricultural wastes 6:175-191.

Haug, R. T. 1993. The practical handbook of composting engineering. Ann Arbor, MI: Lewis publisher.

Hayward, G. and V. Pavlicick .1990. A corrected method for dry matter determination for use in anaerobic digester control. Biological Wastes 34: 101-111.

Islam, M. N., K. J. Park and H. S. Yoon. 2012. Methane production potential of food waste and food waste mixture with swine manure in anaerobic digestion. Journal of Biosystems Engineering 37(2):100-105

Kafle, G. K. and S. H. Kim. 2011. Sludge exchange process on two serial CSTRs anaerobic digestions: Process failure and recovery. Bioresource Technology 102: 6815-6822.

Kafle, G. K., S. H. Kim and B. S. Shin. 2012a. Anaerobic digestion treatment for the mixture of Chinese cabbage waste juice and swine manure. Journal of Biosystems Engineering 37(1):58-64.

Kafle, G. K., S. H. Kim and K. I. Sung. 2012b. Batch anaerobic co-digestion of Kimchi factory waste silage and swine manure under mesophilic conditions. Bioresource Technology (In press).

Kim, D. H. and S. H. Hyun. 2004. Kinetics of thermophilic anaerobic digestion and effects of propionate on thermophilic anaerobic digestion. Journal of Environment Science and Engineering 6:58-63.

Kim, S. H. and G. K. Kafle. 2010. Effective treatment of swine manure with Chinese cabbage silage through two serial anaerobic digestions. Journal of Biosystems Engineering 35(1):53-62.

Korea Ministry of Environment (KME). 2005. The state of solid waste generation and treatment in 2005. Seoul, South Korea.

Kreuger E, I. A. Nges and L. Björnsson. 2011. Ensiling of crops for biogas production: effects on methane yield and total solids determination. Biotechnology for Biofuels 4:44.

Kumar, S., A. N. Mondal, S. A. Gaikward, S. Devotta and R. N. Singh. 2004. Qualitative assessment of methane emission inventory from municipal solid waste disposal sites: a case study. Atmospheric Environment 38:4921-4929.

Li, C., P. Champagne and B. C. Anderson. 2011. Evaluating and modeling biogas production from municipal fat, oil, and grease and synthetic kitchen waste in anaerobic co-digestions. Bioresource Technology 102: 9471-9480.

Lo, H. M., T. A. Kurniawan, M. E. T. Sillanpää, T. Y. Pai, C. F. Chiang, K. P. Chao, M. H. Liu, S. H. Chuang, C. J. Banks, S. C. Wang, K. C. Lin, C. Y. Lin, W. F. Liu, P. H. Cheng, C. K. Chen, H. Y. Chiu and H. Y. Wu. 2010. Modeling biogas production from organic fraction of MSW co-digested with MSWI ashes in anaerobic bioreactors. Bioresource Technology 101: 6329-6335.

Owen, W. F., D. C. Stuckey, J. B. Healy, L. Y. Young and P. L. McCarty. 1979. Bioassay for monitoring biochemical methane potential and anaerobic toxicity. Water Research 13: 485-492.

Raposo, F., R. Borja, M. A. Martín, A. Martín, M. A. de la Rubia and B. Rincón. 2009. Influence of inoculumsubstrate ratio on the anaerobic digestion of sunflower oil cake in batch mode: process stability and kinetic evaluation. Chemical Engineering Journal 149: 70-77.

Richards, B. K., R. J. Uummings, T. E. White and W. Jewell. Methods for kinetic analysis of methane fermentation in high solids biomass digesters. 1999. Biomass and Bioenergy 1(2):65 73.

Shin, J. D., S. S. Han, K. C. Eom, S. Sung, S. W. Park and H. Kim. 2008. Predicting methane production potential of anaerobic co-digestion of swine manure and food waste. Environmental Engineering Research 13(2): 93-97.

VDI 4630. 2006. Fermentation of organic materials: characterization of the substrate, sampling, collection 
Kafle and Kim. Kinetic Study of the Anaerobic Digestion of Swine Manure at Mesophilic Temperature: A Lab Scale Batch Operation

Journal of Biosystems Engineering • Vol. 37, No. 4, $2012 \cdot$ www.jbeng.org

of material data, fermentation tests. In: Verein Deutscher Ingenieure (Ed.), VDI Handbuch Energietechnik, Beuth Verlag GmbH, 10772 Berlin, Germany.

Zhang, L., Y. W. Lee and D. Jahng. 2011. Anaerobic codigestion of food waste and piggery wastewater: Focusing on the role of trace elements. Bioresource
Technology 102(8):5048-5059.

Zhang, R. H., Y. Yin, S. Sung and R. R. Dague. 1997. Anaerobic treatment of swine waste by the anaerobic sequencing batch reactor. Transactions of the ASAE 40(3):761-767. 